\title{
Uromyces appendiculatus in Honduras: Pathogen Diversity and Host Resistance Screening
}

Maricelis Acevedo, Department of Plant Pathology, North Dakota State University, Fargo 58108; James R. Steadman, Department of Plant Pathology, University of Nebraska-Lincoln, Lincoln 68583; and Juan C. Rosas, Escuela Agrícola Panamericana-Zamorano, Tegucigalpa, Honduras

\begin{abstract}
Acevedo, M., Steadman, J. R., and Rosas, J. C. 2013. Uromyces appendiculatus in Honduras: Pathogen diversity and host resistance screening. Plant Dis. 97:652-661.

Bean rust, caused by the fungus Uromyces appendiculatus, is a major constraint for common bean production worldwide. Virulence of $U$. appendiculatus collected from wild and cultivated Phaseolus spp. was examined in 28 locations across Honduras. Host accessions representing wild and domesticated Phaseolus spp. collected at the same sampling locations were evaluated for resistance against $U$. appendiculatus. In total, 91 pathotypes were identified from 385 U. appendiculatus isolates according to their virulence on each of the 12 host differentials. No significant difference in pathogen total virulence, measured as the mean disease score, was found between locations. However, significant differences were found in pathotype virulence among isolates collected from different Phaseolus spp. within a location. Moreover, when locations were compared on the basis of pathotype occurrence and frequency, differences among locations were evident. No two locations had the same pathotype composition. The most common patho-

type was virulent on 9 of the 12 differential lines. A high number of resistant accessions were identified in Phaseolus coccineus and $P$. lunatus. Although most wild $P$. vulgaris accessions were highly susceptible, rust resistance was observed in $P$. vulgaris landraces collected from farmer's fields. Thirty-two (52\%) of the accessions screened showed intermediate to high levels of resistance and, of those, $16 \%$ were $P$. coccineus accessions. Our findings support the hypothesis that interaction of $U$. appendiculatus in host populations composed of diverse Phaseolus spp. and genotypes has favored highly diverse and virulent pathotypes, creating a center for virulence diversity of the pathogen in Honduras. The high percentage of intermediate and highly resistant accessions identified in the present study supports the strategy of collecting plants from the center of diversity of a pathogen or in locations with high incidence of disease and pathogen diversity to maximize the probability of identifying new sources of resistance.
\end{abstract}

Bean rust, caused by the fungus Uromyces appendiculatus, is a major constraint for common bean production around the world. $U$. appendiculatus epidemics have been most serious in tropical and subtropical areas in the Americas and Africa but severe epidemics have also occurred in temperate climates. A high virulence diversity in $U$. appendiculatus in many geographic regions has been documented $(14,21,23,33,39,40,41,44)$. Despite the high number of virulence patterns described worldwide, two major pathotype groups can be distinguished in $U$. appendiculatus. One of the pathotype groups is virulent on common bean cultivars of Andean origin while the second pathotype group is virulent on common bean cultivars of both the Andean gene pool and the Middle American gene pool $(2,23)$. Based on these results, parallel evolution of host and pathogen has been suggested.

Disease resistance is the least expensive and easiest management strategy in most common bean production systems, especially in developing countries where common bean crops are mainly produced by small-scale farmers (24). However, the high pathogenic and genetic variability of the common bean rust fungus has challenged the development of resistant varieties. This challenge is enhanced in the tropics, where multiple common-bean-growing seasons occur in a single year and a conducive environment and adequate moisture favor the development of rust epidemics and pathogen diversity.

Many rust resistance genes have been identified using specific pathotypes of the bean rust pathogen. These genes include $U r-3$, $U r-4, U r-5, U r-6, U r-7, U r-9 / U r-12, U r-11, U r-13 U r$-Ouro Negro,

Corresponding author: M. Acevedo, E-mail: Maricelis.Acevedo@ndsu.edu

Accepted for publication 12 October 2012.

http://dx.doi.org/10.1094/PDIS-02-12-0169-RE

(c) 2013 The American Phytopathological Society and $U r$-Resisto. Other sources of resistance have been identified in bean cultivars and lines but the inheritance of the resistance is not fully understood or has yet to be determined (see Liebenberg et al. [15] for an inclusive list of the sources of rust resistance and their origin). Despite the availability of many sources of resistance to bean rust pathotypes or physiological races, none of these sources are effective against all races. Gene pyramiding or stacking has been used effectively to produce bean cultivars with multiple rust resistances in several bean market classes $(29,30,42,43,45)$.

Rust diversity studies have shown high virulence and pathogenic diversity in Honduras $(2,14)$. However, no specific cultivars or lines have been developed that are resistant to $U$. appendiculatus populations in Honduras. An understanding of pathogen virulence variability in natural host populations can provide insights into the evolution of pathogen virulence, aid the search for new sources of resistance, and guide resistance gene deployment. Based on the challenge that high virulence diversity represents for breeding rustresistant bean cultivars, especially for Honduras, sources of rust resistance need to be identified to ensure broader and durable resistance in common bean cultivars for the Honduran market. Thus, the objectives of this study were to (i) characterize the virulence diversity of $U$. appendiculatus collected from wild and domesticated populations of Phaseolus spp. in geographically diverse areas of Honduras, (ii) collect and screen Honduran wild and domesticated Phaseolus spp. for rust resistance, and (iii) assess the importance of the occurrence of domesticated and wild Phaseolus spp. in Honduras on U. appendiculatus virulence diversity throughout the country.

\section{Materials and Methods}

Pathogen origin. Collection areas for $U$. appendiculatus urediniospores and Phaseolus spp. seed in Honduras were selected based on the wild bean climate probability GIS-model-based map developed by the International Center of Tropical Agriculture (3) and bean production regions in Honduras. Seed of the landraces 
were obtained from farmer fields. In total, 28 locations were sampled between November and December 2002 to 2005 (Table 1). Rust-infected leaves were collected from wild and domesticated common bean stands in the highlands of Honduras. Wild hosts included Phaseolus vulgaris and $P$. coccineus, while the domesticated hosts included P. vulgaris (common bean), $P$. coccineus, and $P$. vulgaris snap bean from farmer fields. A rust sample was defined as $U$. appendiculatus urediniospores present on a group of four to six leaves collected from one or more plants of each host species at each location. Due to the indeterminate, climbing growth habit of common bean plants in wild settings, individual plants could not be distinguished; thus, no attempt was made to compare rust samples from individual host plants of the same species. Individual rust samples were air dried in glassine envelopes before storing for further processing.

Bean germplasm origin. Rust resistance evaluations were conducted on 74 common bean accessions, including 30 wild $P$. vulgaris, 18 P. vulgaris landraces, 3 P. lunatus, 11 wild and 11 domesticated $P$. coccineus, and 1 wild $P$. vulgaris to a $P$. vulgaris landrace introgression (introgression status determined by plant or seed phenology). The accessions were grown from seed collected in
Honduras from plants with or without common bean rust symptoms (Table 2). Seed were increased in greenhouses at the University of Nebraska-Lincoln West Central Research and Extension Center at North Platt, NE during the fall of 2003 and 2004. Additional seed of the accessions were obtained from the wild bean germplasm collection at the Escuela Agrícola PanamericanaZamorano, Honduras.

Pathogen characterization. Urediniospores from field samples were collected by spraying leaves with a $0.01 \mathrm{M}$ Tween-20 solution and then removing the urediniospores with an artist's paint brush. The brush containing the spore-Tween mixture was then rubbed on the primary leaves of susceptible 'Pinto UI114' grown in a greenhouse for inoculum increase. Each inoculated plant was placed in a mist chamber for $24 \mathrm{~h}$ at $21 \pm 1^{\circ} \mathrm{C}$, then transferred to a greenhouse at $22 \pm 2{ }^{\circ} \mathrm{C}$ into an isolation chamber enclosed with cheesecloth. After 14 days, urediniospores were dislodged by tapping the infected leaves onto a piece of waxed paper, then transferred into a plastic vial. Each vial was placed in a desiccator for $48 \mathrm{~h}$ to reduce moisture content. Samples were stored at $-20^{\circ} \mathrm{C}$ until used for characterization. The virulence characteristics of each urediniospore sample was determined by the disease reaction

Table 1. Sample identification (ID), location, location ID number, Phaseolus host type, and number of isolates per sample of Uromyces appendiculatus field samples collected in Honduras during November and December 2002 to 2005

\begin{tabular}{|c|c|c|c|c|c|}
\hline Sample ID & Collection year & Phaseolus spp. & Location & Location ID & Number of isolates per sample \\
\hline HON02a-11 & 2002 & Phaseolus coccineus & San Juancito 1 & 12 & 6 \\
\hline HON02a-20 & 2002 & P. coccineus & San Juancito 4 & 15 & 5 \\
\hline HON03-02 & 2003 & P. coccineus & La Esperanza 1 & 4 & 8 \\
\hline HON03-03 & 2003 & P. coccineus & La Esperanza 2 & 5 & 8 \\
\hline HON03-04 & 2003 & P. coccineus & Marcala 1 & 7 & 7 \\
\hline HON03-07 & 2003 & P. coccineus & Marcala 2 & 8 & 9 \\
\hline HON04-04 & 2004 & P. coccineus & Buena Vista & 1 & 10 \\
\hline HON05-13 & 2005 & P. coccineus & La Esperanza 2 & 5 & 10 \\
\hline HON05-18 & 2005 & P. coccineus & Marcala 2 & 8 & 7 \\
\hline HON05-16 & 2005 & P. coccineus & Marcala 3 & 9 & 5 \\
\hline HON05-10 & 2005 & P. coccineus & Sta. Lucia 1 & 17 & 3 \\
\hline HON05-10 & 2005 & P. coccineus & Sta. Lucia 1 & 17 & 9 \\
\hline HON05-08 & 2005 & P. coccineus & Sta. Lucia 4 & 20 & 8 \\
\hline HON02a-27 & 2002 & P. coccineus (wild) & San Juancito 2 & 13 & 7 \\
\hline HON02a-30 & 2002 & P. coccineus (wild) & San Juancito 3 & 14 & 2 \\
\hline HON03-22 & 2003 & P. coccineus (wild) & San Francisco & 11 & 12 \\
\hline HON03-19 & 2003 & P. coccineus (wild) & Sta. Lucia 1 & 17 & 13 \\
\hline HON03-16 & 2003 & P. coccineus (wild) & Yuscaran 2 & 28 & 9 \\
\hline HON02a-48 & 2002 & P. vulgaris & Tatumbla 4 & 24 & 5 \\
\hline HON02a-18 & 2002 & P. vulgaris & Tatumbla 5 & 25 & 8 \\
\hline HON03-12 & 2003 & P. vulgaris & Galera Mateo & 2 & 6 \\
\hline HON04-01 & 2004 & P. vulgaris & Buena Vista & 1 & 6 \\
\hline HON04-02 & 2004 & P. vulgaris & Buena Vista & 1 & 10 \\
\hline HON04-07 & 2004 & P. vulgaris & Palmichal & 10 & 13 \\
\hline HON04-05 & 2004 & P. vulgaris & Santa Barbara & 16 & 23 \\
\hline HON05-17 & 2005 & P. vulgaris & Marcala 3 & 9 & 5 \\
\hline HON02-13 & 2002 & P. vulgaris (wild) & Guinope & 3 & 7 \\
\hline HON02a-23 & 2002 & P. vulgaris (wild) & San Juancito 1 & 12 & 13 \\
\hline HON02a-28 & 2002 & P. vulgaris (wild) & San Juancito 3 & 14 & 2 \\
\hline HON02a-15 & 2002 & P. vulgaris (wild) & Tatumbla 1 & 21 & 9 \\
\hline HON02a-16 & 2002 & P. vulgaris (wild) & Tatumbla 2 & 22 & 8 \\
\hline HON02a-17 & 2002 & P. vulgaris (wild) & Tatumbla 3 & 23 & 8 \\
\hline HON02a-29 & 2002 & P. vulgaris (wild) & Yuscaran 1 & 27 & 4 \\
\hline HON03-09 & 2003 & P. vulgaris (wild) & La Majada Mateo1 & 6 & 10 \\
\hline HON03-10 & 2003 & P. vulgaris (wild) & La Majada Mateo1 & 6 & 11 \\
\hline HON03-11 & 2003 & P. vulgaris (wild) & La Majada Mateo1 & 6 & 9 \\
\hline HON03-17 & 2003 & P. vulgaris (wild) & Tatumbla 1 & 21 & 6 \\
\hline HON03-18 & 2003 & P. vulgaris (wild) & Tatumbla 1 & 21 & 3 \\
\hline HON03-13 & 2003 & P. vulgaris (wild) & Yerba Buena Mateo & 26 & 14 \\
\hline HON03-14 & 2003 & P. vulgaris (wild) & Yerba Buena Mateo & 26 & 11 \\
\hline HON03-15 & 2003 & P. vulgaris (wild) & Yerba Buena Mateo & 26 & 5 \\
\hline HON05-03 & 2005 & P. vulgaris (wild) & Sta. Lucia 2 & 18 & 12 \\
\hline HON05-04 & 2005 & P. vulgaris (wild) & Sta. Lucia 3 & 19 & 5 \\
\hline HON05-06 & 2005 & P. vulgaris (wild) & Sta. Lucia 3 & 19 & 6 \\
\hline HON05-01 & 2005 & P. vulgaris (wild) & Tatumbla 1 & 21 & 8 \\
\hline HON05-19 & 2005 & P. vulgaris (wild) & Yerba Buena Mateo & 26 & 4 \\
\hline HON05-20 & 2005 & P. vulgaris (wild) & Yerba Buena Mateo & 26 & 7 \\
\hline HON05-21 & 2005 & P. vulgaris (wild) & Yerba Buena Mateo & 26 & 9 \\
\hline Total & $\ldots$ & $\ldots$ & $\ldots$ & $\ldots$ & 385 \\
\hline
\end{tabular}


Table 2. Origin of 74 Phaseolus accessions collected in Honduras used for common bean rust (Uromyces appendiculatus) resistance tests

\begin{tabular}{|c|c|c|}
\hline $\begin{array}{l}\text { Accession } \\
\text { identification } \\
\text { number }\end{array}$ & Location & Phaseolus spp. \\
\hline 02-011-1B & Santa Lucia & Introgression \\
\hline 03-020-7A & Cabañas, Marcala & Phaseolus coccineus (landrace) \\
\hline $03-021-2 \mathrm{~A}$ & Galeras, Mateo & P. coccineus (landrace) \\
\hline 03-019-1 & La Esperanza & P. coccineus (landrace) \\
\hline 03-019-2 & La Esperanza & P. coccineus (landrace) \\
\hline 03-019-3 & La Esperanza & P. coccineus (landrace) \\
\hline 03-020-1 & Marcala & P. coccineus (landrace) \\
\hline $03-020-3$ & Marcala & P. coccineus (landrace) \\
\hline $03-020-5$ & Marcala & P. coccineus (landrace) \\
\hline $01-016-2 \mathrm{~A}$ & San Juancito & P. coccineus (landrace) \\
\hline $02-012-6$ & Santa Lucia & P. coccineus (landrace) \\
\hline 01-017-4 & Tatumbla & P. coccineus (landrace) \\
\hline 01-006-3B & Guinope & P. coccineus (wild) \\
\hline $01-006-4$ & Guinope & P. coccineus (wild) \\
\hline $01-006-5$ & Guinope & P. coccineus (wild) \\
\hline $01-006-6 \mathrm{~B}$ & Guinope & P. coccineus (wild) \\
\hline 01-006-7B & Guinope & P. coccineus (wild) \\
\hline 01-006-8B & Guinope & P. coccineus (wild) \\
\hline $01-007-2$ & Guinope & P. coccineus (wild) \\
\hline $02-016-6 \mathrm{~A}$ & San Juancito & P. coccineus (wild) \\
\hline $02-016-6 \mathrm{~B}$ & San Juancito & P. coccineus (wild) \\
\hline $01-002-1$ & Tatumbla & P. coccineus (wild) \\
\hline $01-002-3$ & Tatumbla & P. coccineus (wild) \\
\hline 01-001-1B & Tatumbla & P. lunatus (wild) \\
\hline $01-008-1$ & Villa San Francisco & P. lunatus (wild) \\
\hline $01-008-2 \mathrm{C}$ & Villa San Francisco & P. lunatus (wild) \\
\hline 03-020-7B & Cabañas, Marcala & $P$. vulgaris (landrace) \\
\hline 03-020-7C & Cabañas, Marcala & P. vulgaris (landrace) \\
\hline 03-020-8 & Cabañas, Marcala & P. vulgaris (landrace) \\
\hline 02-014-2 & Distrito Central & P. vulgaris (landrace) \\
\hline 03-021-2B & Galeras, Mateo & P. vulgaris (landrace) \\
\hline $03-021-3$ & Galeras, Mateo & P. vulgaris (landrace) \\
\hline 03-018-3A & Joya Grande & P. vulgaris (landrace) \\
\hline $03-021-4 \mathrm{~A}$ & Las Tablas, Mateo & P. vulgaris (landrace) \\
\hline 03-021-4B & Las Tablas, Mateo & P. vulgaris (landrace) \\
\hline $03-021-5 \mathrm{~A}$ & Lepaterique & P. vulgaris (landrace) \\
\hline 03-021-5B & Lepaterique & P. vulgaris (landrace) \\
\hline 03-020-2 & Marcala & P. vulgaris (landrace) \\
\hline $03-020-4$ & Marcala & P. vulgaris (landrace) \\
\hline 03-020-6 & Marcala & P. vulgaris (landrace) \\
\hline 01-004-3 & S. A. de Oriente & P. vulgaris (landrace) \\
\hline 02-016-5B & San Juancito & P. vulgaris (landrace) \\
\hline $01-012-3$ & Santa Lucia & P. vulgaris (landrace) \\
\hline $02-011-1 \mathrm{C}$ & Santa Lucia & P. vulgaris (landrace) \\
\hline 01-014-1 & Distrito Central & P. vulgaris (wild) \\
\hline 01-006-1 & Guinope & P. vulgaris (wild) \\
\hline $01-006-2$ & Guinope & P. vulgaris (wild) \\
\hline 01-006-3A & Guinope & P. vulgaris (wild) \\
\hline 01-006-6A & Guinope & P. vulgaris (wild) \\
\hline 01-006-7A & Guinope & P. vulgaris (wild) \\
\hline 01-006-8A & Guinope & P. vulgaris (wild) \\
\hline 01-007-1 & Guinope & P. vulgaris (wild) \\
\hline $02-018-2$ & Joya Grande & P. vulgaris (wild) \\
\hline $03-021-1 \mathrm{~A}$ & La Majada, Mateo & P. vulgaris (wild) \\
\hline 03-021-1B & La Majada, Mateo & P. vulgaris (wild) \\
\hline 01-004-1 & S. A. de Oriente & P. vulgaris (wild) \\
\hline 01-016-3 & San Juancito & P. vulgaris (wild) \\
\hline 01-016-4 & San Juancito & P. vulgaris (wild) \\
\hline 02-016-2B & San Juancito & P. vulgaris (wild) \\
\hline $01-015-1$ & Santa Lucia & P. vulgaris (wild) \\
\hline 01-010-1 & Santa Lucia & P. vulgaris (wild) \\
\hline 01-011-1A & Santa Lucia & P. vulgaris (wild) \\
\hline 01-012-1 & Santa Lucia & P. vulgaris (wild) \\
\hline $01-001-1 \mathrm{~A}$ & Tatumbla & P. vulgaris (wild) \\
\hline $01-001-2$ & Tatumbla & P. vulgaris (wild) \\
\hline 01-001-3 & Tatumbla & P. vulgaris (wild) \\
\hline $01-002-2$ & Tatumbla & P. vulgaris (wild) \\
\hline $01-002-4$ & Tatumbla & P. vulgaris (wild) \\
\hline 02-017-2B & Tatumbla & P. vulgaris (wild) \\
\hline $02-018-1$ & Tatumbla & P. vulgaris (wild) \\
\hline 01-009-1 & Valle de Angeles & P. vulgaris (wild) \\
\hline $01-008-2 B$ & Villa San Francisco & P. vulgaris (wild) \\
\hline 01-008-7A & Villa San Francisco & P. vulgaris (wild) \\
\hline 03-021-6A & Yerba Buena, Mateo & P. vulgaris (wild) \\
\hline
\end{tabular}

on the primary leaves of one plant of each line of a set of the new 12 standard common bean rust differentials (46). Each of the differential lines or cultivars contains a different source of common bean rust resistance (Table 3). Pinto UI114 was included in each differential set as a susceptible control. The rust inoculum was prepared in a hand sprayer by adding approximately $2.5 \mathrm{mg}$ of urediniospores in $30 \mathrm{ml}$ of a $0.004 \%$ Tween- 20 solution. The urediniospore suspension was sprayed onto plants at primary leaf stage followed by $24 \mathrm{~h}$ of incubation in a mist chamber. After incubation, each differential set was placed in the greenhouse in a cheesecloth chamber to prevent cross-contamination. Disease reaction on each differential was determined 8 to 10 days after inoculation using a hand lens with sizing scale and a 1-to- 6 grading scale based on uredinium diameter (Table 4). If more than one uredinium size was found on the same plant, each size was recorded in order of their frequency. Each isolate was inoculated onto differential sets at least twice to confirmed disease reaction.

To obtain single uredinium isolates (SUIs), closed single uredinia were cut out of each differential plant and inoculated onto a 6-day-old plant of the same differential line to obtain enough spores for a virulence test. This procedure was repeated for every uredinium size present on each of the 12 differential lines. Urediniospores produced from each SUI were considered one $U$. appendiculatus isolate. Disease reaction of each isolate on each of the 12 differential lines was determined 14 days after inoculation. This procedure was repeated at least twice for each isolate to verify disease reaction.

Data analysis. For statistical analysis of the virulence patterns of the $U$. appendiculatus isolates obtained, the 1-to-6 common bean rust grading scale was converted to quantitative disease scores, as described by Mmbaga et al. (23). In brief, this quantitative scale assigns a numerical value to disease reactions that contain more than one uredinium size on the same differential (Table 4). A mean disease score (MDS) was calculated for each isolate using the quantitative disease score (23). The MDS of an isolate is the average disease score of the 12 differentials and was used as a measure of the degree of total virulence of each of the pathotypes. To identify the variables that contributed to virulence variation among isolates, an analysis of variance was performed on the MDS of the isolates. To test effects of location and host type within location, the SAS PROC GLM for a mixed model was utilized (version 9.0; SAS Institute Inc.). Location and host type within location were considered random effects.

The virulence diversity among the SUI collected was assessed by grouping the isolates into pathotypes based on rust reaction similarity on the set of 12 bean differential lines. For this purpose, the quantitative disease scores of each differential were transformed into a binary code where resistant reactions were given a value of 0 and susceptible reactions were assigned a value of 1 . The binary matrix was then used in the NTSYS pc software system (version 2.0; Applied Biostatistics Inc.) to compare all rust isolates MDS. The simple match coefficient was used to create a similarity matrix. This matrix was used in the sequential agglomerative hierarchical nested clustering program using the unweighted pair group method average procedure. Each cluster of isolates was considered a unique rust pathotype. A difference of one reaction on a single differential was considered sufficient to classify the isolates into a different pathotype (cluster). To further describe the pathogen diversity in each location, the total number of pathotypes, pathotype frequency in each location, and pathotype virulence pattern were determined. The pathogen virulence pattern was determined based on the virulence or avirulence reaction on each differentia line.

Pathogen isolates used for resistance screening. Based on the results from the characterization of the $U$. appendiculatus isolates on the 12 bean differential set, six isolates representing the most common pathotypes were used to screen the Phaseolus spp. accessions (Table 5). In addition, Andean-gene-pool-specific and nongene-pool-specific pathotypes were represented in the resistance screening in greenhouse evaluations because both rust pathotype 
groups are found in Honduras. A mixture of isolates was not used to enable identification of resistance to each pathotype used.

Germplasm evaluation. Inoculum of each rust isolate was prepared by adding $5 \mathrm{mg}$ of urediniospores of each pathotype into a hand sprayer containing $60 \mathrm{ml}$ of water containing 4\% Tween-20. Four 6- to 10-day-old plants (fully-expanded primary leaf stage) of each accession and the susceptible control Pinto UI114 were inoculated and incubated as previously described with each of the six $U$. appendiculatus isolates. Disease reaction of each plant was recorded 14 days after inoculation using the standard 1-to-6 scale. An accession was considered resistant to a pathotype if disease reactions were 1,2 or 3 on the scale. Plants with disease reactions of 4 to 6 were considered susceptible. To rule out adult plant resistance (resistance that is manifested in mature plants but not in the younger, seedling stages), each accession plant was reinoculated with the same isolates 4 weeks after the first inoculation. Only leaves from the fourth internode or higher were scored for adult-plant resistance.

In all, 21 accessions that exhibited resistance to a broad array of isolates, and for which there was sufficient available seed, were selected for a second resistance test. In the second test, the plants were grown as described above and inoculated with four isolates that showed nine or more virulent reactions (highly virulent pathotypes) on the 12 differential lines set (Table 5). In order to confirm the disease reactions, each inoculation was performed twice.

In total, 35 accessions that showed intermediate or high levels of resistance in greenhouse evaluations and 11 highly susceptible accessions (as susceptible controls) were evaluated for rust resistance under field conditions at the Escuela Agrícola Panamericana-Zamorano, Honduras, using a mixture of local isolates. In a nonreplicated 5-m row in the field plot, 50 seeds of each accession were planted. In addition, 12 seeds of each accession were planted in a $1.2-\mathrm{m}$ row in an irrigated nursery to promote higher disease pressure. Young plants were inoculated 14 days after planting and then once every week after, until symptoms were observed in susceptible controls. Disease reactions were rated on the standard 1to-6 scale, 64 and 80 days after planting. The accessions were classified as resistant or susceptible based on rust reactions, as described earlier. In addition, disease severity (percentage of leaf area covered with uredinia) was determined for each accession. A disease severity of less than $1 \%$ was considered as highly resistant, between 1 and $20 \%$ was considered intermediate, and disease severity of more than $20 \%$ was considered to be a susceptible reaction.

\section{Results}

Virulence diversity. In total, 385 isolates were recovered from the 28 locations sampled in Honduras. The cluster analysis based on MDS of the 12 individual differentials separated the isolates into 91 pathotypes based on rust reaction similarity on the 12 common bean differential set (Table 5). The virulence complexity of

Table 3. Common bean differential cultivars used to characterize isolates of Uromyces appendiculatus

\begin{tabular}{llll}
\hline $\begin{array}{l}\text { Differential } \\
\text { number }\end{array}$ & \multicolumn{1}{c}{$\begin{array}{c}\text { Cultivar } \\
\text { or line }^{\mathbf{a}}\end{array}$} & \multicolumn{1}{c}{$\begin{array}{c}\text { Resistance } \\
\text { gene }\end{array}$} & \multicolumn{1}{c}{ Gene pool } \\
\hline 1 & Early Gallatin & $U r-4$ & Andean \\
2 & Redlands Pioneer & $U r-13$ & Andean \\
3 & Montcalm & Unknown & Andean \\
4 & PC-50 & $U r-9, U r-12$ & Andean \\
5 & Golden Gate Wax & $U r-6$ & Andean \\
6 & PI 260418 & Unknown & Andean \\
7 & GN1140 & $U r-7$ & Middle America \\
8 & Aurora & $U r-3$ & Middle America \\
9 & Mexico 309 & $U r-5$ & Middle America \\
10 & Mexico235 & $U r-3+$ & Middle America \\
11 & CNC & Unknown & Middle America \\
12 & PI 181996 & $U r-11$ & Middle America \\
\hline
\end{tabular}

${ }^{\text {a }}$ Standard common bean differential set (45). CNC $=$ Compuesto Negro Chimaltenengo. the 91 pathotypes varied from 3 virulent reactions to 11 virulent reactions on the 12 differentials cultivars or lines (Table 5). In all, 6 pathotypes, comprising $5.7 \%$ of the total isolates, were only virulent on differential lines of Andean origin (Andean-gene-pool specific) whereas 44 pathotypes (67.2\% of the isolates) were virulent on 8 or more differential cultivars or lines. None of the pathotypes were virulent on all 12 differentials. The predominant pathotype, number 43 , with a virulence complexity of nine virulent reactions, represented $22.9 \%$ of the isolates and was present in 20 of the 28 host populations. The frequency of this pathotype in the 28 populations varied from 0 to $75 \%$. The 10 most frequent pathotypes represented $69.6 \%$ of all isolates. None of the pathotypes was found in every population. Nevertheless, 58 pathotypes, $15.1 \%$ of all isolates, were found only once.

Each of the 28 host stands (locations) was composed of a unique subset of $U$. appendiculatus pathotypes, and the frequency of the shared pathotypes varied among locations. However, the pathogen total virulence was similar across locations, as revealed by the lack of significant difference for the MSD between locations $(P=$ $0.5819)$. However, there was a significant difference for the isolates MDS among hosts within locations $(P=0.0085)$.

Germplasm greenhouse evaluation. In total, $32(52.5 \%)$ of the 61 Phaseolus accessions screened for rust resistance under greenhouse conditions showed intermediate to high levels of resistance to at least four of the six pathotypes used in the first screening test (Tables 6 and 7). Of these 32 resistant accessions, 10 were $P$. coccineus, 14 were $P$. vulgaris landraces, 3 were $P$. lunatus, 4 were wild $P$. vulgaris, and 1 was an introgression from wild into a $P$. vulgaris landrace (determined by its phenology). All 21 accessions inoculated on the second screening test were resistant to one or more of the highly virulent pathotypes of $U$. appendiculatus (Table 8 ). A higher number of resistant accessions was detected in $P$. coccineus and $P$. vulgaris accessions collected from La Esperanza and Marcala locations. On the other hand, accessions from Villa San Francisco, Guinope, Santa Lucia, and San Juancito were more diverse in disease reactions. Overall, the accessions were more susceptible to isolates that were capable of overcoming resistance genes derived from the Middle American gene pool, such as $U r-3$, $U r-3+$, and $U r-11$.

Field evaluation. In total, 46 accessions were evaluated for rust resistance against a mixture of local pathotypes in field test in Honduras. Of these accessions, 35 were previously selected as intermediately or highly resistant to $U$. appendiculatus pathotypes under greenhouse conditions. Field evaluation results showed higher resistance present in wild and domesticated $P$. coccineus as well as in P. lunatus (Table 9). However, five wild $P$. vulgaris that were considered susceptible during the greenhouse

Table 4. Disease reaction types used to grade virulence of 385 isolates of Uromyces appendiculatus on each of the 12 common bean rust differential lines and their corresponding converted quantitative disease scores used for statistical analysis

\begin{tabular}{llcl}
\hline $\begin{array}{l}\text { Reaction } \\
\text { type }^{\mathbf{a}}\end{array}$ & \multicolumn{1}{c}{ Symptom description } \\
\hline 1 & No visible symptom & Score $^{\mathbf{b}}$ & $\begin{array}{c}\text { Rust } \\
\text { reaction }^{\mathbf{b}}\end{array}$ \\
2 & Necrotic spots without sporulation & 2.1 & Resistant \\
2,3 & Reaction 2 with few type 3 & 2.4 & Resistant \\
3,2 & Reaction 3 with few type 2 & 2.7 & Resistant \\
3 & Uredinia < 0.3 mm in diameter & 3.1 & Resistant \\
3,4 & Reaction 3 with few type 4 & 3.4 & Susceptible \\
4,3 & Reaction 4 with few type 3 & 3.7 & Susceptible \\
4 & Uredinia 0.3-0.49 mm in diameter & 4.1 & Susceptible \\
4,5 & Reaction 4 with few type 5 & 4.4 & Susceptible \\
5,4 & Reaction 5 with few type 4 & 4.7 & Susceptible \\
5 & Uredinia 0.5-0.8 mm in diameter & 5.1 & Susceptible \\
5,6 & Reaction 5 with few type 6 & 5.4 & Susceptible \\
6,5 & Reaction 6 with few type 5 & 5.7 & Susceptible \\
6 & Uredinia 0.8-1.2 mm in diameter & 6.1 & Susceptible \\
\hline
\end{tabular}

a According to Stavely et al. (40).

${ }^{\mathrm{b}}$ Quantitative disease score according to Mmbaga et al. (24). 
Table 5. Pathotype frequency, virulence complexity, and virulence pattern of the 91 Uromyces appendiculatus pathotypes identified in the 385 Honduran isolates based on virulence on each of the 12 bean rust differentials

\begin{tabular}{|c|c|c|c|c|}
\hline $\begin{array}{l}\text { Pathotype } \\
\text { number }\end{array}$ & $N^{\mathrm{a}}$ & $\begin{array}{c}\text { Pathotype } \\
\text { frequency (\%) }\end{array}$ & Virulence pattern $^{\mathbf{b}}$ & Pathotype distribution across populations ${ }^{\mathrm{c}}$ \\
\hline 1 & 88 & 22.86 & $1,2,3,4,5,6,7,9,11$ & $1,2,3,4,5,6,7,8,10,11,12,14,16,17,22,23,24,25,26,28$ \\
\hline 2 & 41 & 10.65 & $1,2,3,4,5,6,7$ & $2,5,6,8,9,11,12,15,17,19,24,26$ \\
\hline 3 & 33 & 8.57 & $1,2,3,4,5,6,7,8,9,10,11$ & $1,3,4,6,7,10,11,16,17,18,22,23,26,28$ \\
\hline 4 & 25 & 6.49 & $1,2,3,4,5,6,7,8,9,11$ & $1,3,4,6,10,13,14,16,17,21,22,28$ \\
\hline 5 & 19 & 4.94 & $1,2,3,4,5,6,7,11$ & $8,17,18,22,26,28$ \\
\hline 6 & 18 & 4.68 & $1,2,3,4,5,6,7,9$ & $3,5,6,7,8,10,11,13,17,20,22,24,27,28$ \\
\hline 7 & 17 & 4.42 & $1,2,3,4,5,6$ & $5,6,8,912,13,18,19,20,26$ \\
\hline 8 & 12 & 3.12 & $1,2,3,4,5,6,7,9,11,12$ & $5,6,9,13,22,24$ \\
\hline 9 & 8 & 2.08 & $1,3,4,5,6,7$ & $6,12,19,23,26$ \\
\hline 10 & 7 & 1.82 & $1,2,3,4,5,6,7,8,9$ & $1,12,14,16,21,26$ \\
\hline 11 & 5 & 1.3 & $1,2,3,4,5,6,7,9,10,11$ & $6,12,22,23,26$ \\
\hline 12 & 4 & 1.04 & $1,2,3,5,6,7,9$ & $14,19,26$ \\
\hline 13 & 4 & 1.04 & $1,3,5,6,7$ & $8,12,26$ \\
\hline 14 & 3 & 0.78 & $1,2,3,4,5,6,7,8,9,10$ & $5,13,21$ \\
\hline 15 & 3 & 0.78 & $1,2,3,4,5,7,8,9,11$ & $6,12,16$ \\
\hline 16 & 3 & 0.78 & $1,3,4,5,6$ & $7,20,23$ \\
\hline 17 & 3 & 0.78 & $1,3,4,5,6,7,9$ & $12,23,27$ \\
\hline 18 & 3 & 0.78 & $2,3,4,5,6,7,9,11$ & 1 \\
\hline 19 & 3 & 0.78 & $2,3,5,6,7,9,11$ & 1 \\
\hline 20 & 2 & 0.52 & $1,2,3,4,5,6,11$ & 17,19 \\
\hline 21 & 2 & 0.52 & $1,2,3,4,5,6,7,12$ & 22 \\
\hline 22 & 2 & 0.52 & $1,2,3,4,5,6,7,8,9,11,12$ & 6,7 \\
\hline 23 & 2 & 0.52 & $1,2,3,4,5,7,9,11$ & 1,6 \\
\hline 24 & 2 & 0.52 & $1,2,3,5,6,7,9,11,12$ & 5,9 \\
\hline 25 & 2 & 0.52 & $1,3,4,5,6,7,8,9,10,11$ & 12,18 \\
\hline 26 & 2 & 0.52 & $1,3,4,5,6,7,8,9,11$ & 10,24 \\
\hline 27 & 2 & 0.52 & $1,3,5,6,7,8,9,11$ & 19,25 \\
\hline 28 & 2 & 0.52 & $1,3,5,6,7,9,11$ & 1,10 \\
\hline 29 & 2 & 0.52 & $2,3,4,5,6$ & 18 \\
\hline 30 & 2 & 0.52 & $2,3,4,5,6,7,8,9,10,11$ & 6,16 \\
\hline 31 & 2 & 0.52 & $3,4,5,6,7,9,11$ & $1,10,19,25$ \\
\hline 32 & 2 & 0.52 & $3,4,6,7,8,9,10,11$ & 1,18 \\
\hline 33 & 2 & 0.52 & $3,6,7,8,9,10,11$ & 16 \\
\hline 34 & 1 & 0.26 & $1,2,3,4,5,6,11,12$ & 5 \\
\hline 35 & 1 & 0.26 & $1,2,3,4,5,6,7,11,12$ & 5 \\
\hline 36 & 1 & 0.26 & $1,2,3,4,5,6,7,8,10,12$ & 27 \\
\hline 37 & 1 & 0.26 & $1,2,3,4,5,6,7,8,9,10,12$ & 1 \\
\hline 38 & 1 & 0.26 & $1,2,3,4,5,6,7,9,10,11$ & 15 \\
\hline 39 & 1 & 0.26 & $1,2,3,4,5,6,7,9,10,11,12$ & 5 \\
\hline 40 & 1 & 0.26 & $1,2,3,4,5,6,7,9,10$ & 6 \\
\hline 41 & 1 & 0.26 & $1,2,3,4,5,6,7,9,12$ & 18 \\
\hline 42 & 1 & 0.26 & $1,2,3,4,5,6,8$ & 23 \\
\hline 43 & 1 & 0.26 & $1,2,3,4,5,6,8,9$ & 15 \\
\hline 44 & 1 & 0.26 & $1,2,3,4,5,6,9$ & 26 \\
\hline 45 & 1 & 0.26 & $1,2,3,4,5,7$ & 5 \\
\hline 46 & 1 & 0.26 & $1,2,3,4,5,7,11$ & 6 \\
\hline 47 & 1 & 0.26 & $1,2,3,4,5,7,8,9,10,11$ & 5 \\
\hline 48 & 1 & 0.26 & $1,2,3,4,6,7$ & 26 \\
\hline 49 & 1 & 0.26 & $1,2,3,4,6,7,8,9$ & 10 \\
\hline 50 & 1 & 0.26 & $1,2,3,4,6,7,9$ & 23 \\
\hline 51 & 1 & 0.26 & $1,2,3,5,6$ & 17 \\
\hline 52 & 1 & 0.26 & $1,2,3,5,6,7$ & 21 \\
\hline 53 & 1 & 0.26 & $1,2,3,5,6,7,11$ & 18 \\
\hline 54 & 1 & 0.26 & $1,2,3,5,6,7,8,9,10,11,12$ & 19 \\
\hline 55 & 1 & 0.26 & $1,2,3,5,6,7,9,12$ & 19 \\
\hline 56 & 1 & 0.26 & $1,2,3,5,6,9$ & 22 \\
\hline 57 & 1 & 0.26 & $1,2,3,5,7$ & 6 \\
\hline 58 & 1 & 0.26 & $1,2,4,5,7,8,9,11$ & 6 \\
\hline 59 & 1 & 0.26 & $1,3,4,5,6,11$ & 5 \\
\hline 60 & 1 & 0.26 & $1,3,4,5,6,7,8,9$ & 24 \\
\hline 61 & 1 & 0.26 & $1,3,4,5,6,7,8,9,10$ & 24 \\
\hline 62 & 1 & 0.26 & $1,3,4,5,6,7,9,10,11$ & 1 \\
\hline 63 & 1 & 0.26 & $1,3,4,5,6,7,9,11$ & 3 \\
\hline 64 & 1 & 0.26 & $1,3,4,5,7,9,11$ & 1 \\
\hline 65 & 1 & 0.26 & $1,3,4,6,7,8,9,10,11$ & 18 \\
\hline 66 & 1 & 0.26 & $1,3,5$ & 6 \\
\hline 67 & 1 & 0.26 & $1,3,5,6$ & 12 \\
\hline
\end{tabular}

\footnotetext{
${ }^{\mathrm{a}}$ Number of isolates per pathotype.

${ }^{\mathrm{b}}$ Virulence reactions on the 12 common bean rust differentials. Numbers correspond to each common bean differential line's number with a susceptible reaction. Differential lines 1 to 6 belong to the Andean gene pool and 7 to 12 belong to Middle American gene pool.

${ }^{\mathrm{c}}$ Numbers correspond to each of the 28 locations sampled as provided in Table 1.
} 
Table 5. (continued from preceding page)

\begin{tabular}{|c|c|c|c|c|}
\hline $\begin{array}{l}\text { Pathotype } \\
\text { number }\end{array}$ & $N^{\mathbf{a}}$ & $\begin{array}{c}\text { Pathotype } \\
\text { frequency }(\%)\end{array}$ & Virulence pattern ${ }^{b}$ & Pathotype distribution across populations ${ }^{\mathrm{c}}$ \\
\hline 68 & 1 & 0.26 & $1,3,5,6,7,8,10$ & 19 \\
\hline 69 & 1 & 0.26 & $1,3,5,6,7,8,9$ & 21 \\
\hline 70 & 1 & 0.26 & $1,3,5,6,7,8,9,10,11,12$ & 16 \\
\hline 71 & 1 & 0.26 & $1,3,5,6,7,9$ & 3 \\
\hline 72 & 1 & 0.26 & $1,3,5,6,7,9,12$ & 18 \\
\hline 73 & 1 & 0.26 & $1,3,5,6,8,9,11$ & 20 \\
\hline 74 & 1 & 0.26 & $1,3,5,9,11$ & 6 \\
\hline 75 & 1 & 0.26 & $1,3,6,7$ & 21 \\
\hline 76 & 1 & 0.26 & $1,4,5,6,7,8,9,11$ & 22 \\
\hline 77 & 1 & 0.26 & $2,3,4,5,6,7,8,9$ & 17 \\
\hline 78 & 1 & 0.26 & $2,3,4,5,7,9$ & 22 \\
\hline 79 & 1 & 0.26 & $2,3,5,6,7,11$ & $3,22,25$ \\
\hline 80 & 1 & 0.26 & $2,3,5,6,7,8,9,10,11,12$ & 7 \\
\hline 81 & 1 & 0.26 & $2,3,5,7,9,11,12$ & 25 \\
\hline 82 & 1 & 0.26 & $3,4,5,6,7$ & 20 \\
\hline 83 & 1 & 0.26 & $3,4,5,6,7,8,9,10,11$ & 12 \\
\hline 84 & 1 & 0.26 & $3,4,5,6,9,11,12$ & 9 \\
\hline 85 & 1 & 0.26 & $3,4,5,7,8,9,10,11$ & 20 \\
\hline 86 & 1 & 0.26 & $3,4,5,7,9$ & 22 \\
\hline 87 & 1 & 0.26 & $3,5,6,7$ & 26 \\
\hline 88 & 1 & 0.26 & $3,5,6,7,8,9,11$ & 22 \\
\hline 89 & 1 & 0.26 & $3,5,6,7,9,11$ & 19 \\
\hline 90 & 1 & 0.26 & $3,5,6,7,9,12$ & 19 \\
\hline 91 & 1 & 0.26 & $3,5,7,9,11$ & 25 \\
\hline
\end{tabular}

Table 6. Virulence pattern of Uromyces appendiculatus isolates used to evaluate Phaseolus spp. accessions for common bean rust resistance in greenhouse tests

\begin{tabular}{|c|c|c|c|c|c|c|c|c|c|c|c|c|}
\hline \multirow[b]{2}{*}{ Isolate } & \multicolumn{12}{|c|}{ Differential line ${ }^{a}$} \\
\hline & EG & $\mathbf{R P}$ & $\mathbf{M}$ & PC50 & GGW & PI260418 & GN1140 & Aurora & Mex 309 & Mex 235 & CNC & PI181996 \\
\hline HON03-17-01 ${ }^{\mathrm{b}}$ & $\mathrm{S}$ & S & $\mathrm{S}$ & $\mathrm{S}$ & $\mathrm{S}$ & $\mathrm{S}$ & $\mathrm{S}$ & $\mathrm{S}$ & $\mathrm{S}$ & $\mathrm{S}$ & $\mathrm{S}$ & $\mathrm{R}$ \\
\hline HON03-17-04 & $\mathrm{S}$ & $\mathrm{S}$ & $\mathrm{S}$ & $\mathrm{S}$ & $\mathrm{S}$ & $\mathrm{S}$ & $\mathrm{S}$ & $\mathrm{R}$ & $\mathrm{S}$ & $\mathrm{R}$ & $\mathrm{S}$ & $\mathrm{R}$ \\
\hline HON03-02-03 ${ }^{b}$ & $\mathrm{~S}$ & $\mathrm{~S}$ & $\mathrm{~S}$ & $\mathrm{~S}$ & $\mathrm{~S}$ & $\mathrm{~S}$ & $\mathrm{~S}$ & $\mathrm{R}$ & $\mathrm{S}$ & $\mathrm{R}$ & $\mathrm{S}$ & $\mathrm{R}$ \\
\hline HON03-04-P114 & $\mathrm{S}$ & $\mathrm{S}$ & $\mathrm{S}$ & $\mathrm{S}$ & $\mathrm{S}$ & $\mathrm{S}$ & $\mathrm{S}$ & $\mathrm{R}$ & $\mathrm{S}$ & $\mathrm{R}$ & $\mathrm{S}$ & $\mathrm{R}$ \\
\hline HON03-07-P114 & $\mathrm{S}$ & $\mathrm{S}$ & $\mathrm{S}$ & $\mathrm{S}$ & $\mathrm{S}$ & $\mathrm{S}$ & $\mathrm{S}$ & $\mathrm{R}$ & $\mathrm{R}$ & $\mathrm{R}$ & $\mathrm{S}$ & $\mathrm{R}$ \\
\hline HON03-19-07b & $\mathrm{S}$ & $\mathrm{S}$ & $\mathrm{S}$ & $\mathrm{S}$ & $\mathrm{S}$ & $\mathrm{S}$ & $\mathrm{S}$ & $\mathrm{R}$ & $\mathrm{R}$ & $\mathrm{R}$ & $\mathrm{R}$ & $\mathrm{R}$ \\
\hline HON03-7-02 & $\mathrm{S}$ & $\mathrm{S}$ & $\mathrm{S}$ & $\mathrm{S}$ & $\mathrm{S}$ & $\mathrm{S}$ & $\mathrm{S}$ & $\mathrm{R}$ & $\mathrm{S}$ & $\mathrm{R}$ & $\mathrm{S}$ & $\mathrm{S}$ \\
\hline HON03-09-09b & $\mathrm{S}$ & $\mathrm{S}$ & $\mathrm{S}$ & $\mathrm{S}$ & $\mathrm{S}$ & $\mathrm{S}$ & $\mathrm{S}$ & $\mathrm{R}$ & $\mathrm{S}$ & $\mathrm{R}$ & $\mathrm{S}$ & $\mathrm{S}$ \\
\hline HON03-3-11 $1^{\mathrm{c}}$ & $\mathrm{S}$ & $\mathrm{S}$ & $\mathrm{S}$ & $\mathrm{S}$ & $\mathrm{S}$ & $\mathrm{S}$ & $\mathrm{S}$ & $\mathrm{R}$ & $\mathrm{S}$ & $\mathrm{S}$ & $\mathrm{S}$ & $\mathrm{S}$ \\
\hline HON03-4-1 ${ }^{\mathrm{c}}$ & $\mathrm{S}$ & $\mathrm{S}$ & $\mathrm{S}$ & $\mathrm{S}$ & $\mathrm{S}$ & $\mathrm{S}$ & $\mathrm{S}$ & $\mathrm{S}$ & $\mathrm{S}$ & $\mathrm{R}$ & $\mathrm{S}$ & $\mathrm{S}$ \\
\hline
\end{tabular}

a Differential lines: EG = Early Gallatin, RP = Redlands Pioneer, M = Montcalm, and CNC = Compuesto Negro Chimaltenango. Differential reaction to the isolate: $\mathrm{S}=$ susceptible and $\mathrm{R}=$ resistant.

$\mathrm{b}$ Isolates used to screen all accessions in first screening test.

${ }^{\mathrm{c}}$ Isolates used to screen accessions that show intermediate or high level of resistance in the first test (second screening test).

evaluations showed a moderate level of resistance under field conditions.

\section{Discussion}

This study is the first to characterize the common bean rust fungus, $U$. appendiculatus, in multiple Phaseolus populations in an ecosystem where diverse host populations interact with the pathogen in close proximity. The characterization of 91 pathotypes from the $385 \mathrm{U}$. appendiculatus isolates (one pathotype for every four isolates) from wild and domesticated Phaseolus populations in Honduras clearly confirms the high virulence diversity of this pathogen in Middle America, as reported in previous common bean rust diversity studies $(2,14,23)$. In a study comparing $U$. appendiculatus virulence diversity among individual common bean fields in the United States, Honduras, Dominican Republic, and South Africa, researchers reported that the number of pathotypes in an individual common bean field is highly variable, with common bean fields in Michigan containing only 2 pathotypes whereas up to 25 pathotypes were identified in single common bean fields in Yuscaran and Tatumbla, Honduras (14). Higher virulence of Honduran $U$. appendiculatus pathotypes has also been reported $(2,14,23)$. In a study including 373 rust pathotypes from common bean fields in North, Central, and South America and the Carib- bean, Mmbaga and collaborators (23) found that 9 of the 10 most virulent isolates were obtained from Honduras samples. Of all 385 isolates characterized in our study, $67 \%$ of the isolates were virulent on 8 or more differentials and the predominant pathotype was virulent on 9 of the 12 sources of resistance. None of the 12 differentials was resistant to all the pathotypes isolated from the 28 locations sampled. However, the rust resistance source $U r-11$ present in PI 181996, differential line 12 was susceptible only to $8.5 \%$ of the isolates. The differentials 'Aurora' and 'Mexico 235', carrying the resistant genes $U r-3$ and $U r-3^{+}$, respectively, were also effective against most Honduran pathotypes. Only $1.3 \%$ of all isolates (five pathotypes) were virulent on these three differentials simultaneously. These results suggest that it may be feasible to manage common bean rust pathogen in Honduras by pyramiding rust resistance genes $U r-3, U r-3+$, and $U r-11$ into adapted bean varieties suitable for the Honduran market.

The presence of $\mathrm{U}$. appendiculatus isolates that are virulent on differential lines of Andean origin is not characteristic for areas where bean cultivars mostly of the Middle America gene pool are grown, such as Honduras. Thus, the occurrence of $U$. appendiculatus isolates of both pathotype subgroups (Andean-gene-pool specific and non-gene-pool specific) in Honduras suggests that Honduras may be a center of diversity for this pathogen. Moreover, 
the fact that $U$. appendiculatus isolates from Honduras are highly virulent on differential lines carrying resistance genes from Andean and Middle American origin contrasts with results from other bean pathogens such as Colletotrichum lindemuthianum and Phaseorapsis griseola, in which bean germplasm or cultivars of Andean origin are more resistant to Middle American pathogen isolates and vice versa $(12,31,36)$. To determine whether this is a unique case,
U. appendiculatus virulence diversity should be evaluated more extensively in other countries of Central America, especially those neighboring Honduras such as Guatemala and El Salvador, where wild and domesticated bean grow in proximity. Additionally, it would be of interest to collect pathogen samples from domesticated and wild Phaseolus spp. from the same countries to determine whether the differences in virulence specificity observed in

Table 7. Reaction of Phaseolus spp. accessions to six Honduran Uromyces appendiculatus isolates under greenhouse conditions

\begin{tabular}{|c|c|c|c|c|c|c|}
\hline \multirow[b]{2}{*}{ Accession } & \multicolumn{6}{|c|}{ U. appendiculatus isolate ${ }^{\mathrm{a}}$} \\
\hline & HON03-2-3 & HON03-4-P114 & HON03-7-P114 & HON03-17-4 & HON03-17-1 & HON03-19-7 \\
\hline $01-001-1 \mathrm{~A}$ & 5 & 5 & 5 & 5 & 5 & 5 \\
\hline $01-001-1 \mathrm{~B}^{\mathrm{b}}$ & 2 & 2 & 2 & 1 & 1 & 2 \\
\hline $01-001-2$ & 4,5 & 5 & 5 & 5 & 5 & 5 \\
\hline $01-001-3$ & 1 & 4 & 4 & 4 & 3,4 & 5,4 \\
\hline $01-002-2$ & 4,5 & 4 & 4 & 1 & 5 & 1 \\
\hline $01-002-4$ & 4,5 & 4,5 & 4 & 5 & 3,4 & 5 \\
\hline $01-004-1^{b}$ & 2 & 2 & 2 & 2 & 2 & 1 \\
\hline $01-004-3^{b}$ & 1 & 2 & 1 & 1 & 1 & 1 \\
\hline $01-006-1$ & 1 & 4 & 1 & 5,6 & 5,4 & 5,4 \\
\hline $01-006-2$ & 5 & 4,5 & 4 & 4 & 4 & 5 \\
\hline $01-006-3 \mathrm{~A}^{\mathrm{b}}$ & 1 & 2 & 1 & 1 & 1 & 1 \\
\hline $01-006-6 \mathrm{~A}$ & 5 & 5 & 4 & 5 & 1 & 5 \\
\hline $01-006-7 \mathrm{~A}$ & 4,5 & 5 & 4 & 4,5 & 4,5 & 5 \\
\hline $01-006-8 \mathrm{~A}$ & 5 & 4,3 & 5 & 5 & 1 & 5,4 \\
\hline $01-007-1$ & 5 & 5 & 4 & 4 & 5,4 & 5,4 \\
\hline $01-008-1^{\mathrm{b}}$ & 2 & 3,4 & 1 & 1 & 2 & 2 \\
\hline $01-008-2 B$ & 5 & 1 & 4 & 1 & 4 & 4 \\
\hline $01-008-2 C^{b}$ & 1 & 1 & 1 & 1 & 1 & 1 \\
\hline $01-008-7 \mathrm{~A}$ & 4 & 4 & 4 & 1 & 4 & 4 \\
\hline $01-009-1$ & 4 & 4 & 4 & 4 & 4,5 & 4 \\
\hline $01-010-1$ & 5 & 5,4 & 4 & 4 & 5,4 & 5 \\
\hline $01-011-1 \mathrm{~A}^{\mathrm{b}}$ & 1 & 1 & 1 & 1 & 2 & 1 \\
\hline $01-012-1$ & 5 & 5 & 4 & 5 & 4,5 & 5 \\
\hline $01-012-3^{b}$ & 2 & 2 & 2 & 2 & 2,3 & 2 \\
\hline 01-014-1 & 5 & 4 & 4 & 5 & 5 & 5 \\
\hline $01-015-1$ & 5 & 5 & 4 & 4 & 5 & 4,5 \\
\hline $01-016-2 \mathrm{~A}$ & 5 & 5 & 5,4 & 4 & 4 & 4 \\
\hline $01-016-3$ & 4 & 4,3 & 4 & 4 & 5 & 4 \\
\hline $01-016-4$ & 4 & 4 & 4 & 4 & 4 & 4 \\
\hline $02-011-1 \mathrm{~B}^{\mathrm{b}}$ & 1 & 4 & 2 & 2 & 1 & 2,3 \\
\hline $02-011-1 C^{b}$ & 4 & 2 & 1 & 3,4 & 3,2 & 2 \\
\hline $02-014-2$ & 4 & 4 & 4 & 4 & 1 & 4 \\
\hline $02-016-2 \mathrm{~B}$ & 4 & 4 & 4,5 & 5,4 & 4,5 & 4 \\
\hline $02-016-5 B^{b}$ & 2 & 2,3 & 1 & 4 & 4 & 5 \\
\hline $02-017-2 \mathrm{~B}^{\mathrm{b}}$ & 1 & 1 & 1 & 1 & 1 & 1 \\
\hline $02-018-1$ & 4 & 4 & 4 & 4 & 5 & 4,5 \\
\hline $02-018-2$ & 4 & 5 & 4 & 4 & 1 & 1 \\
\hline $03-018-3 \mathrm{~A}^{\mathrm{b}}$ & 1 & 1 & 1 & 1 & 1 & 1 \\
\hline $03-019-1^{\mathrm{b}}$ & 1 & 3,4 & 1 & 1 & 1 & 1 \\
\hline $03-019-2^{b}$ & 1 & 2 & 1 & 1 & 1 & 1 \\
\hline $03-019-3^{b}$ & 1 & 1 & 1 & 1 & 1 & 1 \\
\hline $03-020-1^{b}$ & 1 & 1 & 1 & 1 & 1 & 1 \\
\hline $03-020-2^{b}$ & 1 & 1 & 1 & 1 & 1 & 1 \\
\hline $03-020-3^{b}$ & 1 & 1 & 1 & 1 & 1 & 1 \\
\hline $03-020-4^{b}$ & 1 & 1 & 1 & 1 & 1 & 1 \\
\hline $03-020-5^{b}$ & 1 & 1 & 1 & 1 & 1 & 1 \\
\hline $03-020-6^{\mathrm{b}}$ & 1 & 1 & 1 & 1 & 1 & 1 \\
\hline $03-020-7 \mathrm{~A}^{\mathrm{b}}$ & 1 & 1 & 1 & 1 & 1 & 1 \\
\hline $03-020-7 \mathrm{~B}^{\mathrm{b}}$ & 2,3 & 3,2 & 2 & 1 & 4 & 3 \\
\hline $03-020-7 C^{b}$ & 1 & 1 & 1 & 1 & 1 & 1 \\
\hline $03-020-8^{b}$ & 1 & 2 & 1 & 1 & 4 & 2 \\
\hline $03-021-1 \mathrm{~A}$ & 5 & 5 & 5 & 4,5 & 5 & 5 \\
\hline $03-021-2 \mathrm{~A}^{\mathrm{b}}$ & 4 & 1 & 1 & 1 & 4,5 & 1 \\
\hline $03-021-2 \mathrm{~B}^{\mathrm{b}}$ & 1 & 1 & 1 & 1 & 5 & 1 \\
\hline $03-021-3^{\mathrm{b}}$ & 1 & 1 & 1 & 1 & 1 & 1 \\
\hline $03-021-4 \mathrm{~A}^{\mathrm{b}}$ & 1 & 4 & 1 & 1 & 3 & 1 \\
\hline $03-021-4 \mathrm{~B}^{\mathrm{b}}$ & 1 & 1 & 1 & 1 & 1 & 1 \\
\hline $03-021-5 \mathrm{~A}^{\mathrm{b}}$ & 1 & 1 & 1 & 1 & 1 & 1 \\
\hline $03-021-5 \mathrm{~B}^{\mathrm{b}}$ & 1 & 1 & 1 & 1 & 4 & 1 \\
\hline $03-21-1 \mathrm{~B}$ & 4,5 & 5 & 5 & 5 & 5 & 5 \\
\hline $03-21-6 A$ & 2 & 5 & 5,4 & 5 & 5 & 5 \\
\hline
\end{tabular}

${ }^{a}$ Disease reaction based on symptom scale of 1 to 6 (40). An accession was considered resistant to a pathotype if no symptoms, necrotic spots, or only uredinia smaller than $300 \mathrm{~nm}$ (1 to 3 in the scale) were present.

b Accessions with intermediate or high levels of rust resistance based on disease reaction to at least four of six isolates. 
other pathosystems is due to the host origin and not solely the geographical location.

The distribution of the 10 most common $U$. appendiculatus pathotypes in the 28 locations sampled made evident the degree of connectivity of most of the fungus populations across Honduras. However, $15 \%$ of the pathotypes were found restricted to a specific population. Genetic or environmental barriers that prevent uniformity and maintain some virulence polymorphism between populations may exist (6). It is also possible that these restricted pathotypes have recently arisen in the population (7).

Based on the analysis of variances, the isolate origin (location) did not have a significant effect on the MDS. This could be due to the fact that $U$. appendiculatus is wind-dispersed, which could facilitate the movement of the pathogen from location to location. On the other hand, significant differences were found among hosts within location for the MDS. The differences in rust resistance within and among Phaseolus spp. growing in close proximity across Honduras suggest that selection pressure, especially that exerted by host species composition, could play an important role in maintaining pathogen virulence diversity within and among populations. Similar findings have been reported for Puccinia graminis $\mathrm{f}$. sp. avenae and $P$. coronata populations, their wild hosts Avena barbata, A. fatua, and A. ludoviciana, and the domesticated species A. sativa and A. striginosa in Australia (26). In Honduras, wild Phaseolus vulgaris and wild $P$. coccineus populations are commonly found in proximity to cultivated common bean. The fact that the MDSs are significantly different for samples collected within a location but from different host species (host within location) provides novel information about maintenance of $U$. appendiculatus virulence diversity in Honduras and for the search for resistance to this highly variable pathogen.

The effect of host species as a selection agent for higher pathogen virulence was evaluated within each location by comparing the pathogen virulence on host variants. In general, common bean rust pathotypes from wild $P$. coccineus had the highest MDS values, followed by rust pathotypes from $P$. vulgaris. Results of rust resistance screening tests performed on collected wild and domesticated hosts showed that wild $P$. vulgaris plants are susceptible to the majority of the rust pathotypes isolated from Honduras populations, while $P$. coccineus (wild and domesticated) as well as some $P$. vulgaris landraces were resistant to the most common rust pathotypes as well as to some rare and highly virulent pathotypes. These results agreed with observations made in multiple previous plant exploration trips to Honduras, where $P$. coccineus and at least two other Phaseolus spp., P. lunatus and P. leptostachyus, were encountered in several locations in Honduras free of rust (J. R. Steadman, personal communication). High levels of resistance such as in $P$. coccineus stands could be acting as a selection agent for highly virulent isolates.

Twenty Phaseolus accessions, including all three $P$. lunatus accessions and wild and cultivated $P$. coccineus, as well as a $P$. vulgaris introgression, were identified as highly resistant to Honduras $U$. appendiculatus pathotypes in greenhouse and field tests. Overall, the accessions were more susceptible to isolates that overcame resistance genes derived from the Middle American gene pool, such as $U r-3, U r-3+$, and $U r-11$. The reaction of the wild $P$. vulgaris accessions that were more resistant in field conditions than in greenhouse evaluations is of interest for breeding purposes. The higher resistance of these accessions in the field can be the result of one or more of the following reasons: difference of virulence pattern of isolates used in greenhouse versus isolates present in the field, timing or host stage at inoculation time (primary leaf inoculation versus young and adult plants), disease pressure (higher inoculum pressure in greenhouse versus lower disease pressure under field conditions), or fluctuating humidity and temperature in the field as opposed to the controlled and optimal environmental conditions of the misting chamber and greenhouses. Moreover, all of the accessions that were susceptible in the greenhouse but were classified as resistant in the field showed a disease reaction type of 4 to 6 (susceptible disease reaction based on 0-to-6 scale) while the disease severity was $4 \%$ or lower. Partial resistance, expressed as lower disease incidence despite a high disease infection type compared with completely susceptible lines, and adult-plant resistance (in contrast with all-stage or seedling resistance) has been previously reported in common bean $(4,5,22,38)$. Adult-plant resistance was not detected in the greenhouse experiment (data not shown). However, only infection type was recorded in the adult-plant stage test in greenhouse. Disease severity, which would provide evidence for partial resistance and adult-plant resistance involving slow rusting, was not recorded in our greenhouse experiment.

Screening of bean germplasm in the search for disease resistance has been previously done by evaluating core collections in which thousands of accessions are tested against one or several pathogen pathotypes or strains $(17,31)$. Although successful for identifying new sources of resistance, this screening method requires extensive resources, time, and space. In addition, the efficiency of such a screening strategy can be limited when the resistance to a pathotype is rare or when dealing with highly variable pathogens. As an example, in the search for sources of resistance to angular leaf spot, only $2.2 \%$ (32 of 1,441) of the common bean accessions in a core collection were found to be resistant to Andean and Mesoamerican pathotypes of Phaseorapsis griseola (17). Similar success rates were reported with other pathogens in comparable studies (32). The high percentage of intermediate and highly resistant accessions identified in the present study provides evidence that plant explorations that collect in the center of diversity of pathogens or in locations with high incidence of disease or pathogen diversity are a very efficient approach for the identification of new sources of resistance that can broaden the genetic base for disease resistance in common bean. Previous studies in different plantpathogen systems, including the Hordeum spontaneoum-Erysiphe graminis hordei and the A. sterilis-Puccinia coronata avenae systems, have shown that resistance genes tend to aggregate in populations occurring in areas favorable for disease development $(25,26,46)$.

Higher levels of resistance were observed in Phaseolus coccineus accessions independent of their collection origin (location) when compared with $P$. vulgaris accessions, which may suggest that rust resistance is a characteristic of the species. This confirms

Table 8. Disease reactions of 21 Phaseolus spp. accessions evaluated for resistance against highly virulent pathotypes of Uromyces appendiculatus

\begin{tabular}{lcccc}
\hline & \multicolumn{4}{c}{ U. appendiculatus isolate } \\
\cline { 2 - 5 } Accession & HON03-3-11 & HON03-4-1 & HON03-17-2 $^{\text {HON03-9-9B }}$ \\
\hline 01-011-1A & 1 & 2 & 1 & 3 \\
03-018-3A & 5 & 2 & 5,4 & - \\
$03-019-1$ & 1 & 1 & 1 & - \\
$03-019-2$ & 1 & 1 & 1 & - \\
$03-019-3$ & 1 & 2 & 1 & - \\
$03-020-1$ & 1 & 1 & 1 & - \\
$03-020-2$ & 2 & - & 5,4 & 1 \\
$03-020-3$ & 2 & 1 & 1 & - \\
$03-020-4$ & 4 & - & 1 & 4 \\
$03-020-5$ & 1 & 1 & 1 & 1 \\
$03-020-6$ & 2 & 1 & 1 & 4 \\
$03-020-7 \mathrm{~A}$ & 1 & 1 & 1 & 1 \\
$03-020-7 \mathrm{~B}$ & 5 & 4,5 & 1 & 4 \\
$03-020-8$ & 2 & 2 & 1 & - \\
$03-021-2 \mathrm{~A}$ & 4 & - & 1 & 3 \\
$03-021-2 \mathrm{~B}$ & 5 & 1 & 5,4 & - \\
$03-021-3$ & 1 & 1 & 1 & 1 \\
$03-021-4 \mathrm{~A}$ & 2,3 & 1 & 1 & 4,5 \\
$03-021-4 \mathrm{~B}$ & 4 & 1 & 5 & 4 \\
$03-021-5 \mathrm{~A}$ & 1 & 1 & 1 & 3 \\
$03-021-5 \mathrm{~B}$ & 5 & 3 & 5,4 & 4 \\
\hline
\end{tabular}

a Disease reaction based on 1-to-6 scale (40). An accession was considered resistant to a pathotype if no symptoms, necrotic spots, or only uredinia smaller than $0.3 \mathrm{~mm}$ diameter ( 1 to 3 in the scale) were present; - indicates that accession was not evaluated with the pathotype because seed were not available. 
previous reports of rust resistance present in $P$. coccineus (10). Accessions of $P$. coccineus have been found resistant to several other bean diseases, including angular leaf spot $(8,17,31)$, ascochyta blight (34), anthracnose $(16,35)$, white mold $(1,13,19)$, Fusarium root rot (47), Bean golden yellow mosaic virus (27), common bacterial blight $(11,20,28,48)$, and web blight $(9,18,48)$. In some cases, these sources of resistance have been successfully introgressed from $P$. coccineus into $P$. vulgaris (37).

Future work should target the characterization of the gene or genes conferring rust resistance in wild $P$. vulgaris and $P$. vulgaris landraces accessions identified in this study with intermediate or high levels of resistance. Moreover, the rust-resistant $P$. vulgaris landraces already have seed size and color of the Honduras market classes (small red and black). This should facilitate the development of commercial cultivars without the unwanted traits that come with introgression from wild germplasm.

\section{Acknowledgments}

This research was supported by the USAID Bean/Cowpea Collaborative Research Support Program (CRSP) and a United States Department of Agriculture plant exploration grant. We thank J. Venegas and R. Ramos for their assistance in collecting bean rust samples that were used in this study and K. M. Eskridge for his assistance with the statistical analysis.

\section{Literature Cited}

1. Abawi, G. S., R. Providenti, Crosier, D. C., and Hunter, J. E. 1978. Inheritance of resistance to white mold disease in Phaseolus coccineus. J. Hered. 69:200-202.

2. Araya, C. M., Alleyne, A. T., Steadman, J. R., Eskridge, K. M., and Coyne, D. 2004. Phenotypic and genotypic characterization of Uromyces appendiculatus from Phaseolus vulgaris in the Americas. Plant Dis. 88:830-836.

3. Beebe S., Castro, A., Rodríguez, F., Varela, O., and Jones, P. 1997. The use of geographical information system to locate wild Phaseolus vulgaris in Honduras. Annu. Rep. Bean Improv. Coop. 40:26-27.

4. Bokosi, J. M., Coyne, D. P., Steadman, J. R., Arnaud-Santana, E., and

Table 9. Reaction of 46 Phaseolus spp. accessions to Uromyces appendiculatus under field conditions in Honduras at 64 days after planting

\begin{tabular}{|c|c|c|c|c|c|}
\hline \multirow[b]{2}{*}{ Accession } & \multicolumn{2}{|c|}{ Field } & \multicolumn{2}{|c|}{ Irrigated nursery } & \multirow[b]{2}{*}{ Overall reaction $^{c}$} \\
\hline & Disease reaction $^{a}$ & Severity $(\%)^{b}$ & Disease reaction $^{a}$ & Severity $(\%)^{\mathbf{b}}$ & \\
\hline $01-001-1 B^{d}$ & 1 & 0 & 1 & 0 & $\mathrm{R}$ \\
\hline $01-001-2^{\mathrm{d}, \mathrm{e}}$ & $5,4,3$ & 1 & 4,5 & $<1$ & I \\
\hline $01-002-2^{\mathrm{d}, \mathrm{e}}$ & $4,3,2$ & 4 & 4 & $<1$ & I \\
\hline $01-002-3$ & 1 & 0 & 1 & 0 & $\mathrm{R}$ \\
\hline $01-004-1^{\mathrm{d}}$ & $4,3,5$ & 1 & $3,4,5$ & 2 & $\mathrm{I}$ \\
\hline $01-006-3 A^{d}$ & 4,3 & 2 & 4 & 4 & $\mathrm{I}$ \\
\hline 01-006-3B & 1 & 0 & 1 & 0 & $\mathrm{R}$ \\
\hline $01-006-4$ & 1 & 0 & 4,3 & $<1$ & $\mathrm{R}$ \\
\hline $01-006-6 \mathrm{~A}^{\mathrm{d}, \mathrm{e}}$ & $4,5,6$ & 1 & 4 & $<1$ & $\mathrm{I}$ \\
\hline $01-006-6 B^{d}$ & 1 & 0 & 1 & 0 & $\mathrm{R}$ \\
\hline 01-006-7B & 1 & 0 & 1 & 0 & $\mathrm{R}$ \\
\hline $01-008-1^{\mathrm{d}}$ & 1 & 0 & 1 & 0 & $\mathrm{R}$ \\
\hline $01-008-2 C^{d}$ & 1 & 0 & 1 & 0 & $\mathrm{R}$ \\
\hline $01-009-1^{\mathrm{d}}$ & 3,4 & 8 & 4 & 10 & I \\
\hline $01-010-1^{\mathrm{d}}$ & $4,3,5$ & 1 & 4,3 & 1 & $\mathrm{I}$ \\
\hline $01-011-1 \mathrm{~A}^{\mathrm{d}}$ & 4 & $<1$ & 4,3 & $<1$ & $\mathrm{R}$ \\
\hline $01-012-1^{\mathrm{d}, \mathrm{e}}$ & 1 & 0 & 5,4 & $<1$ & $\mathrm{R}$ \\
\hline $01-012-3^{d}$ & 4,5 & 80 & 3,4 & 50 & $\mathrm{~S}$ \\
\hline $01-014-1^{\mathrm{d}}$ & $4,5,3$ & 60 & 6,3 & 1 & $\mathrm{~S}$ \\
\hline $01-016-2 \mathrm{~A}^{\mathrm{d}}$ & 3 & $<1$ & 1 & 0 & $\mathrm{R}$ \\
\hline $02-011-1 B^{d}$ & $4,5,6$ & 40 & 5,4 & 5 & $\mathrm{~S}$ \\
\hline $02-011-1 C^{d}$ & $4,5,6$ & 25 & 4,5 & 4 & $\mathrm{~S}$ \\
\hline $02-014-2^{\mathrm{d}, \mathrm{e}}$ & 5,4 & 4 & 4 & 1 & I \\
\hline $02-016-5 B^{d}$ & $4,5,3,6$ & 3 & 3,4 & 1 & I \\
\hline $02-017-2 B^{d}$ & $4,3,5$ & 1 & 5,4 & 1 & I \\
\hline $03-018-3 \mathrm{~A}^{\mathrm{d}}$ & $5,4,6$ & 5 & 5,4 & 2 & $\mathrm{I}$ \\
\hline $03-019-1^{\mathrm{d}}$ & 1 & 0 & 1 & 0 & $\mathrm{R}$ \\
\hline $03-019-2^{\mathrm{d}}$ & 1 & 0 & 1 & 0 & $\mathrm{R}$ \\
\hline $03-019-3^{\mathrm{d}}$ & 1 & 0 & 2 & $<1$ & $\mathrm{R}$ \\
\hline $03-020-1^{\mathrm{d}}$ & 1 & 0 & 6,3 & $<1$ & $\mathrm{R}$ \\
\hline $03-020-2^{\mathrm{d}}$ & $4,3,5$ & $<1$ & 3 & $<1$ & $\mathrm{R}$ \\
\hline $03-020-3^{\mathrm{d}}$ & 1 & 0 & 1 & 0 & $\mathrm{R}$ \\
\hline $03-020-4^{\mathrm{d}}$ & 1 & 0 & 3 & $<1$ & $\mathrm{R}$ \\
\hline $03-020-5^{\mathrm{d}}$ & 1 & 0 & 1 & 0 & $\mathrm{R}$ \\
\hline $03-020-6^{\mathrm{d}}$ & 4,5 & $<1$ & 4,3 & $<1$ & $\mathrm{R}$ \\
\hline $03-020-7 \mathrm{~A}^{\mathrm{d}}$ & 1 & 0 & 1 & 0 & $\mathrm{R}$ \\
\hline $03-020-7 B^{d}$ & $4,5,3$ & 1 & 5,6 & 5 & $\mathrm{I}$ \\
\hline $03-020-7 C^{d}$ & 1 & 0 & 3 & 1 & $\mathrm{R}$ \\
\hline $03-020-8^{\mathrm{d}}$ & 4,5 & 2 & 3,4 & $<1$ & $\mathrm{I}$ \\
\hline $03-021-2 \mathrm{~A}^{\mathrm{d}}$ & 1 & 0 & 1 & 0 & $\mathrm{R}$ \\
\hline $03-021-2 B^{d}$ & $4,5,6$ & 4 & $-^{\mathrm{f}}$ & $-^{\mathrm{f}}$ & I \\
\hline $03-021-3^{\mathrm{d}}$ & 1 & 0 & 1 & 0 & $\mathrm{R}$ \\
\hline $03-021-4 A^{d}$ & 3,4 & 1 & 1 & 0 & $\mathrm{R}$ \\
\hline $03-021-4 B^{d}$ & $4,5,6$ & 5 & 5,3 & $<1$ & $\mathrm{I}$ \\
\hline $03-021-5 \mathrm{~A}^{\mathrm{d}}$ & 1 & $<1$ & 1 & 0 & $\mathrm{R}$ \\
\hline $03-021-5 B^{d}$ & $4,5,6$ & 2 & 5,4 & $<1$ & I \\
\hline
\end{tabular}

a Disease reaction based on 1-to-6 scale (40).

b Percentage of infected leave area.

${ }^{c}$ Overall field disease reaction based on disease reaction and severity. Accessions were classified as resistant $(\mathrm{R})=<1 \%$, intermediate $(\mathrm{I})=1$ to $20 \%$, or susceptible $(\mathrm{S})=>20 \%$.

d Accessions evaluated for common bean rust resistance in greenhouse tests.

e Accessions that showed susceptible reaction in greenhouse screening has a resistant or intermediate overall disease reaction in field tests.

f No plants available for evaluation. 
O'Keefe, D. 1994. Inheritance of specific and adult plant rust (Uromyces appendiculatus) resistance and leaf pubescence in dry bean (Phaseolus vulgaris L.). HortScience 29:470.

5. Bokosi, J. M., Coyne, D. P., Steadman, J. R., and O'Keefe, D. 1994. Sources of adult plant resistance to rust in Malawian bean lines. Annu. Rep. Bean Improv. Coop. 37:61-62.

6. Burdon, J. J., Jaroz, A. M., and Kirby, G. C. 1989. Pattern and patchiness in plant-pathogen interactions-causes and consequences. Annu. Rev. Ecol. Syst. 20:119-136.

7. Burdon, J. J., and Silk, J. 1997. Sources and patterns of diversity in plantpathogenic fungi. Phytopathology 87:664-669.

8. Busogoro, J. P., Jijakli, M. H., and Lepoivre, P. 1999. Identification of novel sources of resistance to angular leaf spot disease of common bean within the secondary gene pool. Plant Breed. 118:417-423.

9. Coyne, D. P., Steadman, J. R., Godoy-Lutz, G., Gilbertson, R., Arnaud Santana, E., Beaver, J. S., and Myers, J. R. 2003. Contributions of the bean/cowpea CRSP to management of bean diseases. Field Crops Res. 82:155-168.

10. Fiume, F. 1995. Identification of varieties of Phaseolus vulgaris L. and Phaseolus coccineus L. with resistance to Uromyces appendiculatus (Pers.) Unger. (Abstr.) Rev. Plant Pathol. 74:356.

11. Freytag, G. F., Basset, M. J., and Zapata, M. 1982. Registration of XR-2351-1 bean germplasm. Crop Sci. 22:1268-1269.

12. Guzmán, P., Gilbertson. R. L., Nodari, R., Johnson, W. C., Temple, S. R., Mandala, D., Mkandawire, A. B. C., and Gepts, P. 1995. Characterization of variability in the fungus Phaeoisariopsis griseola suggests coevolution with the common bean (Phaseolus vulgaris). Phytopathology 85:600-607.

13. Hunter, J. E., Dickson, M. H., Boettger, M. A., and Cinga, J. A. 1982. Evaluation of plant introductions of Phaseolus spp. for resistance to white mold. Plant Dis. 66:320-322.

14. Jochua, C., Amane, M. I. V., Steadman, J. R., Xue, X., and Eskridge, K. M. 2008. Virulence diversity of the common bean rust pathogen within and among individual bean fields and development of sampling strategies. Plant Dis. 92:401-408.

15. Liebenberg, M. M., Mienie, C. M. S., and Pretorious, Z. A. 2006. The Occurrence of rust resistance gene $U r-13$ in common bean cultivars and lines. Euphytica 150:365-386.

16. Mahuku, G. S., Jara, C., Cajiao, C., and Beebe, S. 2002. Sources of resistance to Colletotrichum lindemuthianum in the secondary gene pool of Phaseolus vulgaris and in crosses of primary and secondary gene pools. Plant Dis. 86:1383-1387.

17. Mahuku, G. S., Jara, C., Cajiao, C., and Beebe, S. 2003. Sources of resistance to angular leaf spot (Phaseoisariopsis griseola) in common bean core collection, wild Phaseolus vulgaris and secondary gene pool. Euphytica 130:303-313.

18. Martinez, N. A., Rosas, J. C., Beaver, J. S., Ferwerda, J. H., and Alameda, M. 2005. Identification of new sources of resistance to web blight of common bean. Annu. Rep. Bean Improv. Coop. 48:130-131.

19. Miklas, P. N., Grafton, K. F., Kelly, J. D., Steadman, J. R., and Silbrnagel, M. J. 1998. Registration of four white mold resistant dry bean germplasm lines: 19365-3, 19365-5, 19365-31 and 92BG-7. Crop Sci. 38:1728

20. Miklas, P. N., Zapata, M., Beaver, J. S., and Grafton, K. F. 1994. Registration of four dry bean germplasm resistant to common bacterial blight: ICB3, ICB-6, ICB-8 and ICB-10. Crop Sci. 39:594.

21. Mmbaga, M. T., and Stavely, J. R. 1988. Pathogenic variability in Uromyces appendiculatus from Tanzania and rust resistance in Tanzanian bean cultivars. Plant Dis. 72:259-262.

22. Mmbaga, M. T., and Steadman, J. R. 1992. Adult plant resistance associated with leaf pubescence in common beans. Plant Dis. 76:1230-1236

23. Mmbaga, M. T., Steadman, J. R., and Eskridge, K. M. 1996. Virulence patterns of Uromyces appendiculatus from different geographical areas and implications for finding durable resistance to rust of common bean. J. Phytopathol. 144:533-541.

24. Mmbaga, M. T., Steadman, J. R., and Stavely, J. R. 1996. The use of host resistance in disease management of rust in common bean. Integr. Pest Manage. Rev. 1:191-200.

25. Moseman, J. G., Nevo, E., and Zohary, D. Resistance of Hordeum sponta- eum collected in Israel to infection with Erysiphe graminis hordei. Crop Sci. 23:1115-1119.

26. Oates, J. D., Burdon, J. J., and Brower, J. B. 1983. Interactions between Avena and Puccinia species. II. The pathogens: Puccinia coronata $\mathrm{Cda}$ and P. graminis Pers. f. sp. avenae Eriks \& Henn. J. Appl. Ecol. 20:585-596.

27. Osorno, J. M., Miklas, P. N, Ferwerda, F., and Beaver, J. S. 2003. Two genes from Phaseolus coccineus $\mathrm{L}$. confer resistance to bean golden yellow mosaic virus. Annu. Rep. Bean Improv. Coop. 46:147-148.

28. Park, S. J., and Dhanvantari, B. N. 1987. Transfer of Common Blight (Xanthomonas campestris pv. phaseoli) resistance from Phaseolus coccineus Lam. to P. vulgaris L. through interspecific hybridization. Can. J. Plant Sci. 67:685-695.

29. Park, S. O., Coyne, D. P., Steadman, J. R., Crosby, K. M., and Brick, M. A. 2004. RAPD and SCAR markers linked to the Ur-6 Andean gene controlling specific rust resistance in common bean. Crop Sci. 44:1799-1807.

30. Pastor-Corrales, M. A. 2003. Sources, genes for resistance and pedigrees of 52 rust and mosaic resistant dry bean germplasm lines released by the USDA Beltsville bean project in collaboration with Michigan, Nebraska and North Dakota agricultural experiment stations. Annu. Rep. Bean Improv. Coop. 46:235-241.

31. Pastor-Corrales, M. A., Jara, C., and Singh, S. P. 1998. Pathogenic variation in sources of and breeding for resistance to Phaseoisariopsis griseola causing angular leaf spot in common bean. Euphytica 103:161-171.

32. Pastor-Corrales, M. A., and Stavely, J. R. 2002. Using specific races of the common bean rust pathogen to detect genes in P. vulgaris. Annu. Rep. Bean Improv. Coop. 45:78-79.

33. Sandlin, C. M., Steadman, J. R., Araya, C. M., and Coyne, D. P. 1999 Isolates of Uromyces appendiculatus with specific virulence to landraces of Phaseolus vulgaris of Andean origin. Plant Dis. 83:108-113.

34. Schmit, V., and Baudoin J. P. 1992. Screening for resistance to Ascochyta blight in populations of Phaseolus coccineus L. and Phaseolus polyanthus Greenman. Field Crops Res. 30:155-165.

35. Schwartz, H. F., Pastor-Corrales, M. A., and Singh, S. 1982. New sources of resistance to anthracnose and angular leaf spot of beans (Phaseolus vulgaris L.). Euphytica 31:741-754.

36. Sicard, D., Michalakis, Y., Dron, M., and Neema, C. 1997. Genetic diversity and pathogenic variation of Colletotrichum lindemuthianum in the three centers of diversity of its host, Phaseolus vulgaris. Phytopathology 87:807813.

37. Singh, S. P. 2001. Broadening the genetic base of common bean cultivars: a review. Crop Sci. 41:1659-1675.

38. Statler, G. D., and McVey, M. A. 1987. Partial resistance to Uromyces appendiculatus in dry edible beans. Phytopathology 77:1101-1103.

39. Stavely, J. R. 1983. The 1982 bean rust nurseries. Annu. Rep. Bean Improv. Coop. 26:46-48.

40. Stavely, J. R. 1984. Pathogenic specialization in Uromyces phaseoli in the United States and rust resistance in beans. Plant Dis. 68:95-99.

41. Stavely, J. R. 1999. Pathogenic variability in Uromyces appendiculatus from Central Africa. Annu. Rep. Bean Improv. Coop. 42:37-38.

42. Stavely, J. R., Kelly, J. D., and Grafton, K. F., 1994. BelMiDak-rustresistant navy dry bean germplasm lines. HortScience 29:709-711.

43. Stavely, J. R., Kelly, J. D., Grafton, K. F., Steinke, J., Steadman J. R., Coyne, D. P., Lindgren, D. T., and Silbernagel, M. J. 1994. Recent rust resistant bean germplasm releases. Annu. Rep. Bean Improv. Coop. 37:247248 .

44. Stavely, J. R., Steadman, J. R., and McMillan, R. T., Jr. 1989. New pathogenic variability in Uromyces appendiculatus in North America. Plant Dis. 73:428-432

45. Steadman, J. R., Pastor-Corrales, M. A., and Beaver, J. S. 2002. An overview of the 3 rd bean rust and 2 nd bean common bacterial blight international workshops. Annu. Rep. Bean Improv. Coop. 45:120-124.

46. Wahl, I. 1970. Prevalence and geographic distribution of resistance to crown rust in Avena sterilis. Phytopathology 60:746-749.

47. Wallace, D. H., and Wilkinson, R. E. 1965. Breeding for Fusarium root rot resistance in beans. Phytopathology 55:1227-1231.

48. Welsh, M. M, and Grafton, K. F. 2001. Resistance to common bacterial blight of bean introgressed from Phaseolus coccineus. HortSicence 36:750-751. 